\title{
Logistics Leverage
}

\author{
Donald J. Bowersox \\ Michigan State University • East Lansing, MI \\ John T. Mentzer \\ The University of Tennessee • Knoxville, TN \\ Thomas W. Speh \\ Miami University • Oxford, $\mathrm{OH}$
}

\begin{abstract}
It is the purpose of this paper to position marketing and logistics relationships in a strategic context. The strategic position of both areas is used to draw conclusions for the future relationships of marketing and logistics and to suggest the need to focus on creating "logistics leverage." Logistics leverage - the ability to achieve marketing advantage through logistics superiority - is accomplished through the resolution of nine key issues. Once resolved, logistics can be exploited to obtain and maintain significant competitive advantage.
\end{abstract}

\section{Introduction}

Much recent attention in both business and research has been devoted to the importance of interfunctional coordination (Crittenden, 1992; Deshpande \& Webster, 1989; Kahn \& Mentzer, 1994; Lichtenthal \& Wilson, 1992; O'Reilly, 1991; Ruekert \& Walker, 1987; St. John, 1991; St. John \& Hall, 1991). Two areas that have received particular scrutiny have been marketing and logistics (Granzin, 1980; Granzin \& Bahn, 1989; Mentzer, 1993; Rinehart, Cooper \& Wagenheim, 1989; Voorhees \& Coppett, 1986; Voorhees, Teas, Allen \& Dinkler, 1988). It is the objective of this paper is to examine the relationship between marketing and logistics within a strategic context. This examination is developed in four parts. In the first part, two catalysts to further integration of marketing and logistics are discussed. In the next part, the integration of marketing and logistics is projected into a strategic context. The third part introduces the concept of logistics leverage and the nine issues that must be resolved to accomplish it. Finally, conclusions for marketing and logistics managers and researchers are presented.

\section{Marketing/Logistics Integration Catalysts}

Although marketing and logistics often receive some degree of integration, two catalysts existing in the business environment are working to make logistics superiority, and its strategic integration with marketing, a necessity for many com- 
panies. Understanding these catalysts better positions how logistics can be deployed as a key strategic resource.

\section{Time and Quality Based Competition}

Time and quality based competition focus on eliminating waste in the form of time, effort, defective units, and inventory in manufacturing-distribution systems (Larsen \& Lusch, 1990; Schonberger \& El Ansary, 1984; Schultz, 1985). The most popular time and quality based concepts are just-in-time (JIT) and quick response (QR).

JIT has many facets and touches almost all aspects of a business enterprise (Bartholomew, 1984; Daugherty \& Spencer, 1990; Frazier, Spekman \& Oh, 1987; Jackson, 1983; Rosenberg \& Campbell, 1985). As a result, purchasing, transportation, inventory, and manufacturing personnel all consider JIT to be indigenous to their performance (Yanacek, 1987). In reality, all these activities, plus marketing, are impacted by the adoption of a JIT system within which logistics becomes the focal point of implementation.

One of the effects of JIT is to direct logistics attention toward an overall procurement, manufacturing, operating, and marketing orientation of the business. Importantly, there are significant marketing benefits that can result from establishing JIT competency - for example, higher customer satisfaction from better quality products with zero defects, more consistent availability, and faster product delivery. Typically, such benefits are fully exploited only if logistics managers are more attuned to internal, supply-side systems and cost control, while integrating with marketing programs and customer requirements.

Quick Response (QR) systems are similar to JIT programs (i.e., the required integration of marketing, purchasing, transportation, inventory, and manufacturing), but differ by the fact that they deal with the distribution of finished products from manufacturers to wholesalers and retailers (Larsen \& Lusch, 1990). Many of the principles of successful QR are similar to the logic that drives JIT. Because QR typically deals with finished product distribution, performance is an integral part of total customer service (Dumaine, 1989). However, the drivers that make most existing QR programs successful are inventory velocity and total cost reduction. Only a limited number of firms have begun to manage $\mathrm{QR}$ programs toward the goal of achieving competitive advantage (Daugherty \& Spencer, 1990). The competitive impetus for such coordination of inventory velocity and cost control with customer satisfaction serves as a catalyst for marketing/logistics integration in finished goods channels. 
More advanced forms of QR, however, focus primarily on customer satisfaction. Recently coined "Service Response Logistics" (Davis \& Manrodt, 1991, 1993; Manrodt \& Davis, 1992), these programs tend to position logistical competency as the core activity aimed at achieving customer satisfaction through inventory availability, timely delivery, less product failure, and, thus, less lost sales or returns/ complaints (Stalk, Evans \& Shulman, 1992). The achievement of such customer satisfaction requires significant integration of logistical competency and marketing performance.

The combined effect of time and quality based systems has been to emphasize the need for marketing/logistics integration as a competitive advantage. While both JIT and QR thrive on interorganizational and interfunctional coordination, such arrangements must be driven by a desire to reduce cost, improve asset utilization, and more effectively service customers. Attention to service response logistics suggests that some significant breakthroughs that capitalize on the strategic impact of marketing/logistics integration are developing.

\section{Efficiency and Effectiveness}

Logistics, by its nature, is quantitative in the measurement of efficiency delivery time, the number of short orders, inventory, and similar operational activities can be readily measured. As a result, logistics practice and research has been more operationally oriented and tended to focus more on economic or efficiency measures of performance. The absolute magnitude of logistics cost has directed many firms to control the expense side of logistics; that is, to manage the process to achieve a level of efficiency.

Although there has been considerable research in the logistics area concerning how logistics impacts customer service (for a review, see Mentzer, Gomes \& Krapfel, 1989), no accepted protocol for measuring customer responsiveness to logistics service levels exists. Further, the traditional focus of logistics research on economic (efficiency) issues rather than behavioral issues has not brought the attention of behavioral researchers in marketing to bear on this problem. Although much research in marketing has been devoted to the behavioral implications of service quality and customer satisfaction/dissatisfaction (for a review, see Zeithaml, Berry \& Parasuraman, 1993), little such research has addressed the behavioral implications of changes in logistics service quality as part of overall marketing strategy (Mentzer, Bienstock \& Kahn, 1993). 
However, cost control (efficiency) without recognition of customer service requirements (effectiveness) will doom any aspect of a marketing effort to failure. Logistics is no exception. The need for a clearly defined linkage between logistics performance, marketing strategy, and their behavioral consequences provides the second, and perhaps most important, catalyst for the implementation of logistics as a strategic marketing tool.

\section{Summary}

Current developments in the business environment and the marketing literature suggest these catalysts are having an impact. There are increasing examples of firms such as Wal-Mart, Target, and Kmart establishing alliances with manufacturers to jointly reduce costs and leverage performance. Further, the recent interest in the marketing literature with relationship marketing (Anderson \& Weitz, 1992; Anderson \& Narus, 1990; Dant \& Schul, 1992; Dwyer, Schurr \& Oh, 1987; Frazier, Spekman \& O’Neal, 1988; Heide \& John, 1992; Larsen \& Lusch, 1990) suggests progress in examining the strategic management of logistics issues in building relationships with customers. Results of such alliances and research scrutiny suggest that issues of efficiency and effectiveness measurement can be jointly resolved and that logistical performance can be integrated into mainstream marketing strategy and research. The reality of such catalysts and the potential to be gained from them argue strongly for in-depth examination of logistical effectiveness in overall marketing strategy and a searching consideration of the key role that logistics plays in creating customer satisfaction.

\section{The Marketing/Logistics Strategic Linkage}

In Porter's (1985) value chain, one of the four support activities (procurement) involves logistics and all of the five primary activities involve logistics (inbound logistics, operations, and outbound logistics), marketing (marketing activities), or both (service). It is interesting to note how these functions are so important and inextricably linked in the value chain and suggests that increased focus be placed on effectively coordinating their interaction.

The foundation of future marketing and logistics integration is strategic. With this goal in mind, Figure 1 utilizes the competitive advantage framework of Day and Wensley (1988) to develop the dimensions of the relationship and position the strategic importance of integrated marketing/logistics. 


\section{Figure 1}

\section{Integrated Strategic Planning}

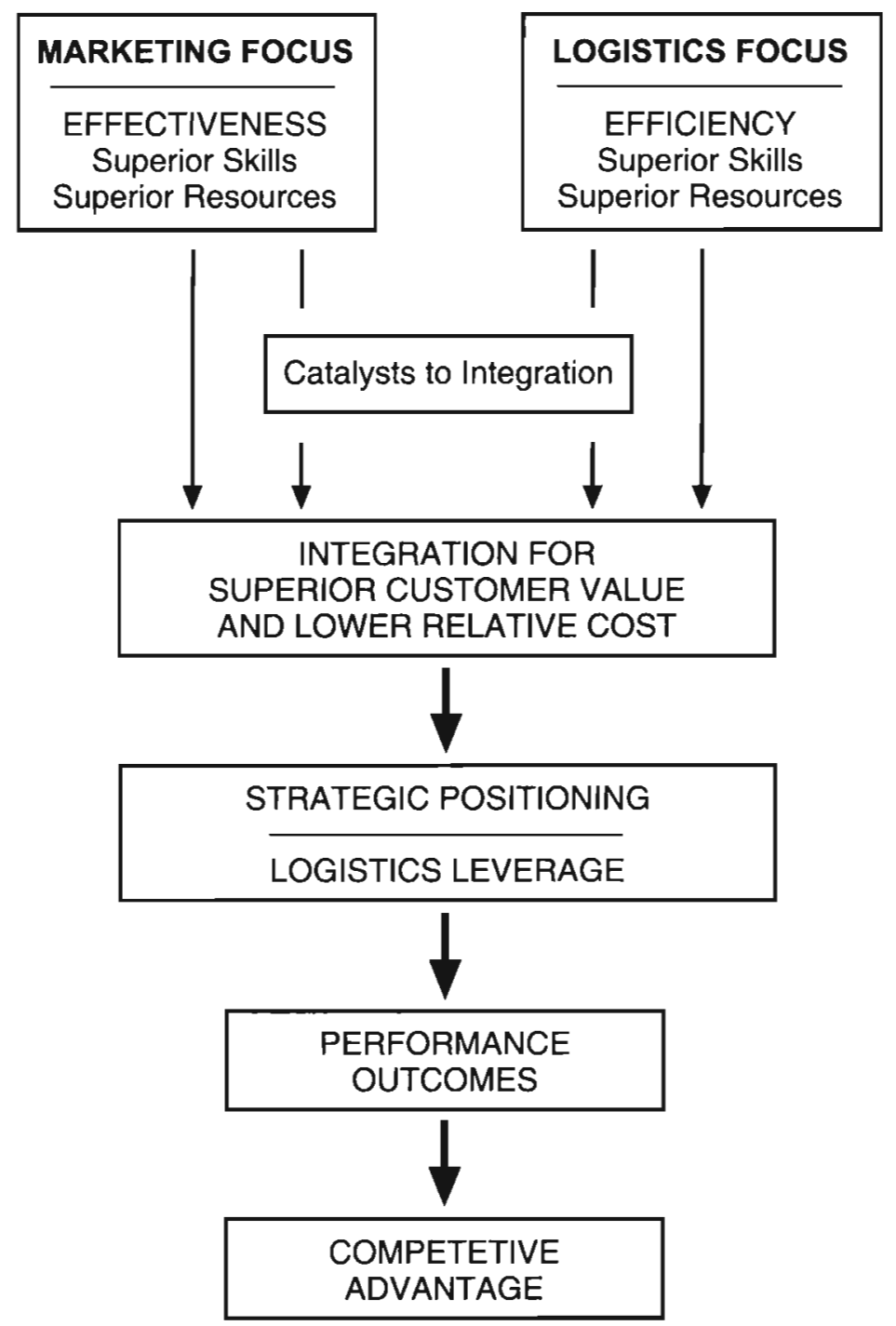

The focus of logistics has been and will primarily continue to be upon cost drivers, i.e. skills and resources that generate efficiency. The integration of marketing and logistics is necessary to bring the logistics sources of advantage into the realm of effectiveness, or drivers of differentiation. This will only occur and result in positional advantages if the leverage logistics can bring to marketing is realized. This leverage can only be realized by recognizing and exploring, both within the practitioner and academic communities, the strategic linkage between marketing and logistics wherein logistics skills and resources are translated into effective drivers of differentiation. Where this integration is accomplished, strategic positioning of the marketing/logistics integrated firm as cost efficient and customer effective 
will result. It will be incumbent upon marketing to emphasize these superior performance outcomes to achieve sustainable competitive advantage.

Firms that have successfully implemented such coordination are now building corporate strategies that exploit logistics competency (Bowersox, Daugherty, Dröge, Germain \& Rogers, 1991). By focusing on logistics competency (e.g., one call for complete order status information, total flexibility in ordering to support either store direct or warehouse delivery, no order minimums), the leading logistics performers are providing tangible and significant benefits to customers. The net result is the creation of a meaningful competitive advantage.

Selected firms are beginning to realize that logistics excellence is a significant differential advantage that can be exploited in the marketplace (Bowersox, et al., 1991). Logistics service is an effective tool for building closer relationships with key customers. Although the expression "being easy to do business with" is over used, the fact remains that some firms are very difficult to buy products from and have poor response systems for providing information concerning such facts as order status and invoice discrepancy. Other firms have state-of-the-art logistics information systems that enable maximum control (Shapiro, Rangan \& Sviokla, 1992; Stalk, Evans \& Shulman, 1992) - a source of advantage which can be translated through integration with marketing into a positional advantage (Day \& Wensley, 1988). The result is the performance outcome of significant customer impact. The final outcome of these superior logistics systems is an added positional advantage of preferred status for selected suppliers - and such status draws directly from the logistics competency (even in situations where price, product, and promotion are undifferentiated or marginally higher in comparison to selected competitors).

As Day and Wensley (1988) observed, "The sustainability of this positional advantage requires that the business set up barriers that make imitation difficult." The true positional advantage of logistics competency is that a Chief Executive Officer cannot, by the whisk of a pen, mandate such competency and automatically obtain the facilities, systems, human resources, and information control necessary to produce a consistent level of logistical performance. As marketing strategies evolve toward greater market segmentation sophistication, the ability to provide customized logistics service to unique segments will become increasingly demanding. Firms with high levels of logistical competence are better positioned to exploit such opportunities. 


\section{Logistics Leverage}

The critical question is how to leverage the strategic benefits inherent in an effective logistics system for maximum competitive advantage. Logistics leverage is the ability to effectively influence market demand through the application of excellent logistics systems, techniques, and programs. The term leverage indicates relatively high market returns may be gained from relatively small investments. Significant sales, market share, and consumer satisfaction gains can be achieved if the firm consciously positions itself to leverage its logistics capabilities. It is not enough to have created the human resources, technical tools, and operational systems for effective logistics, the firm must be able to market and use its logistics expertise to achieve marketing goals. Thus, logistics leverage is based upon successfully resolving nine issues.

\section{Creation of Value-Added Services}

The exploitation of logistics competence offers a meaningful way to create value-added services not achievable in other ways (Cooke, 1990; Mentzer, 1993; Wittersdorf, 1991). Such positioning requires defining critical business processes from a logistics perspective. Such value-added processes have spawned the development of new channel institutions. Logistics facilitation companies are one of the most rapidly growing marketing institutions. Such facilitators do not view themselves as traditional wholesalers, retailers, warehousers, or transportation companies. Their mission vision is one of being a service organization which satisfies a specific niche requirement. They provide logistics economies of scale, essential services, and time and quality based delivery.

The combination of more effective delivery at a lower cost translates to increased value. Thus, what have traditionally been logistics cost drivers are becoming drivers of differentiation (Day \& Wensley, 1988; Porter, 1985). Again, the shift from cost driving logistics activities to logistics drivers of differentiation requires the integration of marketing and logistics activities and strategic plans.

\section{Management Vision}

Top management must fully understand the real and significant market impact that results from logistics superiority. Recent history has demonstrated that many of the successes achieved by large consumer goods firms with mass merchandisers resulted from the manufacturer's ability to lower logistics costs while increasing logistics service, resulting in increased final consumer satisfaction com- 
bined with reduced retailer inventory. These drivers of differentiation were accomplished through management's vision of the potential of logistics and a commitment to leveraging their logistics system for their customers.

Management vision will achieve logistics leverage only if (1) top management applies resources to bring logistics expertise to their customers on a customer-by-customer basis (Davis \& Manrodt, 1991), (2) the attitude of marketing customer satisfaction as a corporate core competency is nurtured by top management throughout the entire organization, not just in marketing, and (3) the logistics benefits of the manufacturer are communicated directly from the supplier CEO to the customer CEO. This latter point is an essential ingredient in the establishment of strategic alliances and partnerships.

\section{Strategic Alliances and Partnerships}

The marketing value of exploiting logistics competency is demonstrated by the positional advantage available as a result of linking firms and their customers into strategic alliances and partnerships. The last decade has witnessed the growth of vertically-integrated marketing systems in a behavioral or relational sense (Dwyer, Shurr \& Oh, 1987; Frazier, Spekman \& O'Neal, 1988; Narus \& Anderson, 1986). The strategic alliances that have evolved are broader in scope than simple out-sourcing because they include risk and reward sharing.

A significant aspect of these newly created alliances is the central role typically played by logistics (Bowersox, 1990). Inventory management, direct-store delivery, warehousing, and transportation consolidation are typical logistics functions that are at the core of many partnerships. The efficient performance of these activities by specialists produces benefits shared by both partners. As Frazier, Spekman, and O'Neal (1988) stated, the emphasis in such relationships is on "the notion of 'total cost of ownership' and the array of value-added services provided."

\section{Strategic Interfunctional Teams}

Logistics superiority as a driver of differentiation can be achieved only when all parties in the marketing organization are integrated in terms of the basic concept of customer satisfaction, the potential of logistics leverage to aid in obtaining customer satisfaction, how the message of logistics customer value needs to be communicated, and to whom this message should be delivered. Team marketing approaches, typically composed of marketing, sales, logistics, finance, and production representatives, are common place and the norm in some industries, with significant 
resultant advantages (Hutt $\&$ Speh, 1984). To achieve logistics leverage, marketing must recognize the role logistics plays in achieving customer satisfaction. Without this recognition, the related promotional, pricing, and "service package" strategies to market logistics expertise to the customer will not be achieved. It falls to logistics to develop and deliver the logistics excellence that marketing has identified as important to customers.

\section{Orientation of Marketing}

For many firms, particularly in the consumer goods industries, the overriding emphasis in marketing personnel training is given to the product and promotional dimensions of marketing strategy. Many factors reinforce this orientation: brand manager organizations; college marketing curricula with an emphasis on advertising, promotion, and product development; and corporate training programs where marketing personnel are given little exposure to logistics. To achieve logistics leverage, colleges and corporations need to rethink the manner in which marketing managers are developed. One step that can be taken by colleges in this leadership role is to make logistics courses required for all business students.

\section{Organizational Issues}

A major premise of this work is that logistics competency can be created, but unless the firm is positioned to exploit it, little strategic significance will result. One way to leverage logistics excellence is to establish hierarchies and reporting relationships that maximize the integrated potential. When marketing, sales, and logistics each report to a separate vice president, each with their own organization, more effort will be required to break down the inherent organizational barriers so that integration is achieved.

Customer teams and matrix management are commonly used to overcome organizational inflexibility (Clark \& Wheelwright, 1992; Gibson, Ivancevich \& Donnelly, 1988; Lawrence, Kolodny \& Davis, 1977). However, since logistics is a customer satisfaction impacting function and its significance as a competitive marketing tool has been demonstrated, logistics should logically be more closely aligned organizationally with marketing. Rather than a team approach, if logistics reports directly to marketing, the potential for maximum market impact of logistics leverage is increased. 


\section{Market Intelligence}

To achieve logistics leverage, information systems need to be restructured so that new and different types of information are routinely gathered and supplied to the marketing/logistics function. Information on customer logistics problems and opportunities are required so the firm can quickly adapt their logistics expertise to meet these challenges. Market research needs to expand from the traditional study of needs, attitudes, and behavior related to product, price, and promotional offerings to include the study of customer logistics needs that customers may not even be aware exist. In addition, environmental assessment studies to benchmark the efforts of those firms deemed to be leaders in logistics excellence will supply strategic information relative to the firm's extant logistics offering.

\section{Channel Member Programs}

To effectively exploit logistics competence, significant efforts may be required to upgrade the logistics systems of other channel members. All channel members must share the vision of the potential market impact of logistics excellence. Without that vision, there will be little hope of developing a marketing program with a logistical focus.

Further, logistics leverage can only be achieved in market segments served by channel members when those members possess the level of logistics excellence required by those customers. This excellence can be developed by careful selection of channel members by market segment, by transferring logistics excellence through strategic alliances, or outsourcing certain traditional channel functions to third party providers.

\section{Sole-Source Relationships}

Finally, the last several years have witnessed increasing efforts by firms to reduce their supplier base and move into sole-source relationships with key suppliers (Bertrand, 1986; Frazier, Spekman \& Oh, 1988; Purchasing, 1989). This trend underscores the need to refocus strategic thinking on the role logistics can play in establishing sole-source relationships. Because of the impact of a vendor's logistics competence on the buyer's costs and operations (just-in-time delivery to production sites, damage-free products, error-free orders, and real-time information are all cost drivers that are potentially also drivers of differentiation for the firm), the vendor's logistics system may be the most effective way to create and support a sole-source relationship. 


\section{Conclusions}

The relationship between the related, but often independently managed, functions of marketing and logistics has been examined. The strength and longevity of the positional advantage from logistics excellence is impressive because of the difficulty of duplicating outstanding logistics systems and the significant benefits they provide to customers from a cost and quality standpoint.

Logistics leverage has to be consciously created through the actions of marketing and logistics managers within the firm. Key issues to be resolved include the creation of value-added services, top management vision, strategic alliances and partnerships, interfunctional teams, the orientation of marketing, organization structure, marketing intelligence, channel member programs, and the nurturing of sole-source relationships. Once these issues are resolved, the firm will be positioned to effectively integrate logistics competence into marketing strategy to create sustainable differential advantage.

Future research and management issues are very much related to the effort to create logistics leverage. Managers and researchers alike need to become more concerned with the buyer behavior implications of changes in the marketing/logistics customer service package. Buyer attitudes and behavior can be expected to change with integrated marketing/logistics efforts (Mentzer, Bienstock \& Kahn, 1993). Whether this altered behavior will be for the good or detriment of the company, and in what degree, lies within the realm of buyer behavior and service quality research - both applied and academic.

Measurement issues should continue to occupy the attention of researchers. Without valid models and predictions of logistics impact on sales, costs, and profits, it is difficult to successfully plot the most meaningful role for logistics in the strategic thrust of a firm. More effective models are needed at two levels: within the channel and at the point of sales to the consumer. Logistics service (in-stock levels, order cycle time, etc.) interacts with a variety of other marketing variables (price, boundary person relationships, location, brand name, advertising claims, etc.) to determine the customer's satisfaction. It will be necessary to expand research efforts to measure these interactions and isolate the specific effect of each variable. Once these effects are better understood, marketing decision-making will be better positioned to make more effective decisions regarding the strategic positioning of logistics services within the overall marketing offering.

The arenas of logistics and channels have long followed separate predominant paradigms - economic for logistics and socio-psychological for channels. 
However, both areas of marketing address the same marketing phenomena - distribution of products. The channels area typically addresses negotiation between channel members, whereas the logistics area addresses the operational interaction between these channel members. These two areas are not separate and cannot be meaningfully managed or researched without recognition of their interaction. The effect of negotiation upon operational reality and vice versa would seem a topic with rich potential for research and managerial creativity. In particular, the application of the transaction cost analysis paradigm (McNeil, 1980; Williamson, 1975, 1985) to the effect of logistics transaction specific investments upon negotiation behavior would seem to be a research area immediately ripe for investigation.

Also within the TCA paradigm, an area of increasing importance is the role of third-party logistics suppliers. Effective logistics competency may be enhanced through the utilization of independent suppliers of a wide array of value-added logistics services. Research, grounded in the transaction cost analysis paradigm, to evaluate the efficiency and effectiveness of out-sourcing logistics functions would help develop the dimensions of how logistics can contribute to maximum strategic impact. By out-sourcing some logistics functions (e.g. warehousing), a firm may gain cost and service advantages not available from internal performance, but incur additional transaction specific investments. As a result, the enhanced level of performance may create a differential advantage that otherwise would not have existed, but come at the cost of increased dependence upon a third party. Being aware that an enhanced performance level is possible at the cost of increased risk permits decision-makers to more effectively assess the contributions of logistics to overall marketing success.

\section{References}

Anderson, E., \& Weitz, B. (1992). The use of pledges to build and sustain commitment in distribution channels. Journal of Marketing Research, 29(February), 18-34.

Anderson, J. C., \& Narus, J. A. (1990). A model of distributor firm and manufacturer firm working partnerships. Journal of Marketing, 54(January), 42-58.

Bartholomew, D. (1984). The vendor-customer relationship today. Production and Inventory Management, (2), 106-21.

Bertrand, K. (1986). Crafting 'win-win situations' in buyer-seller relationships. Business Marketing, 7l(June), 42-50.

Bowersox, D. J. (1990). The strategic benefits of logistics alliances. Harvard Business Review, 68(July-August), 36-45. 
Bowersox, D. J., Daugherty, P. J., Dröge, C. L., Germain, R. N., \& Rogers, D. S. (1991). Logistical excellence: It's not business as usual. New York: Digital Press.

Clark, K. B., \& Wheelwright, S. C. (1992). Organizing and leading 'heavyweight' development teams. California Management Review, (Spring), 9-28.

Cooke, P. N. C. (1990). Value-added strategies in marketing. International Journal of Physical Distribution and Logistics Management, 20(5), 20-24.

Crittenden, V. L. (1992). Close the marketing/manufacturing gap. Sloan Management Review, 33(Spring), 41-52.

Dant, R. P., \& Schul, P. L. (1992). Conflict resolution processes in contractual channels of distribution. Journal of Marketing, 56(January), 38-54.

Daugherty, P. J., \& Spencer, M. S. (1990). Just-in-time concepts, applicability to logistics/transportation. International Journal of Physical Distribution \& Logistics Management, 20(7).

Davis, Jr., F. W., \& Manrodt, K. B. (1991). Principles of service response logistics. Proceedings. Chicago: Council of Logistics Management, 339-55.

Davis, Jr., F. W., \& Manrodt, K. B. (1993). The evolution to service response logistics. International Journal of Physical Distribution and Logistics Management, 22(9), 3-10.

Day, G. S., \& Wensley, R. (1988). Assessing advantage: A framework for diagnosing competitive superiority. Journal of Marketing, 52(April), 1-20.

Deshpande, R., \& Webster, Jr., F. E. (1989). Organizational culture and marketing: Defining the research agenda. Journal of Marketing, 53(January), 3-15.

Dumaine, B. (1989). P\&G rewrites the marketing rules. Fortune, (November), 3448.

Dwyer, F. R., Schurr, P. H., \& Oh, S. (1987). Developing buyer-seller relationships. Journal of Marketing, 5l(April), 11-27.

Frazier, G. L., Spekman, R. E., \& O'Neal, C. R. (1988). Just-in-time exchange relationships in industrial markets. Journal of Marketing, 52(October), 52-67.

Gibson, J. L., Ivancevich, J. M., \& Donnelly, Jr., J. H. (1988). Organizations: Behavior, structure, and processes (6th ed.). Plano, TX: Business Publications, Inc.

Granzin, K. L. (1980). Physical distribution: A description of its structure by means of second-order factor analysis. Journal of Business Research, 8(2), 213-223.

Granzin, K. L., \& Bahn, K. D. (1989). Consumer logistics: Conceptualization, pertinent issues and a proposed program for research. Journal of the Academy of Marketing Science, 17(Winter), 91-102. 
Heide, J. B., \& John, G. (1992). Do norms really matter? Journal of Marketing, 56(April), 32-44.

Hutt, M. D., \& Speh, T. W. (1984). The marketing strategy center: Diagnosing the industrial marketers interdisciplinary role. Journal of Marketing, 48(Fall), 5361.

Jackson, G. C. (1983). Just-in-time production: Implications for logistics managers. Journal of Business Logistics, 4(2), 1-19.

Kahn, K. B., \& Mentzer, J. T. (1994). Norms that distinguish between marketing and manufacturing. Journal of Business Research, 30, 111-118.

Larsen, P. D., \& Lusch, R. F. (1990). Quick response retail technology: Integration and performance measurement. The International Review of Retail, Distribution and Consumer Research, (October), 17-34.

Lawrence, P. R., Kolodny, H. F., \& Davis, S. M. (1977). The human side of the matrix. Organizational Dynamics, (Summer), 47-62.

Lichtenthal, D. J., \& Wilson, D. T. (1992). Becoming market-oriented. Journal of Business Research, 24, 191-207.

Manrodt, K. B., \& Davis, Jr., F. W. (1992). The evolution of service response logistics. International Journal of Physical Distribution and Logistics Management, 22(9), 3-10.

McNeil, I. R. (1980). The new social contract: An inquiry into modern contractual relations. New Haven, CT: Yale University Press.

Mentzer, J. T. (1993). Managing channels in the 21st century. Journal of Business Logistics, 14(1), 27-42.

Mentzer, J. T., Bienstock, C. C., \& Kahn, K. (1993). Customer satisfaction/service quality research: The Defense Logistics Agency. Journal of Consumer Satisfaction, Dissatisfaction and Complaining Behavior, 6, 43-49.

Mentzer, J. T., Gomes, R., \& Krapfel, R. E. (1989). Physical distribution service: A fundamental marketing concept? Journal of the Academy of Marketing Science, 17 (Winter), 53-62.

Narus, J. A., \& Anderson, J. C. (1986). Turn your distributors into partners. Harvard Business Review, 64(March-April), 66-71.

O'Reilly, C. (1991). Corporations, culture, and commitment: Motivation and social control in organizations. In R. M. Steers \& L. W. Porter (Eds.), Motivation and work behavior. New York: McGraw-Hill, Inc.: 242-254.

Porter, M. E. (1985). Competitive advantage: Creating and sustaining superior performance. New York: The Free Press. 
Purchasing. (1989). Buyers keep trimming supplier base despite tight supplies, (February 23), 18.

Rinehart, L. M., Cooper, M. B., \& Wagenheim, G. D. (1989). Furthering the integration of marketing and logistics through customer service in the channel. Journal of the Academy of Marketing Science, 17(Winter), 63-71.

Rosenberg, L. J., \& Campbell, D. P. (1985). Just-in-time inventory control: A subset of channel management. Journal of the Academy of Marketing Science, 13(Summer), 124-133.

Ruekert, R. W., \& Walker, Jr., O. C. (1987). Marketing's interaction with other functional units: A conceptual framework and empirical evidence. Journal of Marketing, 5l(January), 1-19.

Schonberger, R. J., \& El Ansary, A. (1984). Just-in-time purchasing can improve quality. Journal of Purchasing and Materials Management, (Spring), 1-7.

Schultz, D. P. (1985). Just-in-time systems. Stores, (April), 28-31.

Shapiro, B. P., Rangan, V. K., \& Sviokla, J. J. (1992). Staple yourself to an order. Harvard Business Review, 70(July-August), 113-122.

Stalk, G., Evans, P., \& Shulman, L. E. (1992). Competing on capabilities: The new rules of corporate strategy. Harvard Business Review, 70(March-April), 57-69.

St. John, C. H. (1991). Marketing and manufacturing agreement on goals and planned actions. Human Relations, 44(3), 211-229.

St. John, C. H., \& Hall, Jr., E. H. (1991). The interdependency between marketing and manufacturing. Industrial Marketing Management, 20, 223-229.

Voorhees, R. D., \& Coppett, J. I. (1986). "Marketing-logistics opportunities for the 1990's." Journal of Business Strategy, 7 (Fall): 33-38.

Voorhees, R. D., Teas, R. K., Allen, B. J., \& Dinkler, E. T. (1988). Changes in the marketing-logistics relationship. Journal of Business Logistics, 9(1), 34-48.

Williamson, O. E. (1975). Markets and hierarchies, analysis and antitrust implications. New York: The Free Press.

Williamson, O. E. (1985). The economic institutions of capitalism. New York: The Free Press.

Wittersdorf, R. G. (1991). Adding value through logistics management. International Journal of Physical Distribution and Logistics Management, 2l(4), 6-8.

Yanacek, F. (1987). One more just-in-time. Handling and Shipping Management, 28(May), 47.

Zeithaml, V. A., Berry, L. L., \& Parasuraman, A. (1993). The Nature and determinants of customer expectations of service. Journal of the Academy of Marketing Science, 2I(Winter), 1-12. 